\title{
INVESTIGATING VOLCANIC-HYDROTHERMAL SYSTEMS IN DOMINICA, LESSER ANTILLES: TEMPORAL CHANGES IN THE CHEMICAL COMPOSITION OF HYDROTHERMAL FLUIDS FOR VOLCANIC MONITORING USING GEOTHERMOMETERS
}

MAZI-MAZTHIS C. ONYEALI, University of Colorado, Boulder Research Advisors: Holli Frey, Erouscilla Joseph, and Lon Abbott

\section{INTRODUCTION}

Since 2002, the UWI Seismic Research Centre has routinely monitored gas and water chemistry of the hydrothermal areas of Dominica. The primary goal being, that by monitoring changes in the water chemistry of active fumaroles and hot springs, the information can be used to monitor changes in volcanic activity on the island. The waters are predominantly acid-sulfate in character, and likely formed because of dilution of acidic gases in near surface oxygenated groundwater (Joseph et al., 2011). While the waters are of primarily meteoric origin, this study investigates yearly shifts in isotopic composition to explore how evaporation effects, water-rock interaction, and other factors play a role on the general geochemistry. With updated water chemistry data from five hydrothermal areas (Boiling Lake, Valley of Desolation, Sulphur Springs, Watten Waven, Cold Soufriere) for the period 2014 to 2017, we will reevaluate the characteristics of these systems (last reported in 2011) and use geothermometers to evaluate reservoir temperatures.

\section{METHODS}

\section{Field}

Samples were collected in six areas: the Boiling Lake, Valley of Desolation, Sulphur Springs, Watten Waven, Colde Soufriere, Micotrin. In total, twenty-nine features were sampled, with six samples per sampling site. Each set consisted of one alkalinity sample ( 0.2 $\mathrm{mm}$ filter), one sample for analysis of anions, deuterium, and delta ${ }^{18} \mathrm{O}$ (0.2 mm filter); one sample for cations and trace elements $(0.2 \mathrm{~mm}$ filter $)$, preserved with nitric acid; and two samples for dissolved inorganic carbon (raw water).

ProDSS Multiparameter Water Quality Meter (YSI) measured water temperature (Celsius), pressure $(\mathrm{mmHg})$, dissolved oxygen (DO\%), specific conductivity (SPC), conductivity (C), total dissolved solids (TDS), salinity (Sal), $\mathrm{pH}$, and $\mathrm{pH}$ voltage (mV). The YSI was calibrated daily for the most accurate readings.

Lab

Samples were brought to Union College Geoscience $\mathrm{Lab}$ and were analyzed using various equipment. The MetrOhm 888 autotitrator measures for total alkalinity determinations, which is key to finding bicarbonate concentrations $\left(\mathrm{HCO}_{3}{ }^{-}\right.$and $\left.\mathrm{CO}_{3}\right)$. The UIC Coulometrics $^{\mathrm{TM}}$ Carbon Dioxide Coulometer measured organic and inorganic carbon in solid and aqueous phases by oxidizing samples to $\mathrm{CO}_{2}$. Anions and cations were determined using the Dionex-Ion Chromatograph and the software Chromeleon.

The Delta S Mass Spectrometer and Ecotainer is used for analyzing delta ${ }^{18} \mathrm{O}$. The water sample was injected into a high-temperature carbon reactor, which converts it into $\mathrm{H}_{2}$ and $\mathrm{CO}$. The $\mathrm{H}_{2}$ and $\mathrm{CO}$ are separated by gas 


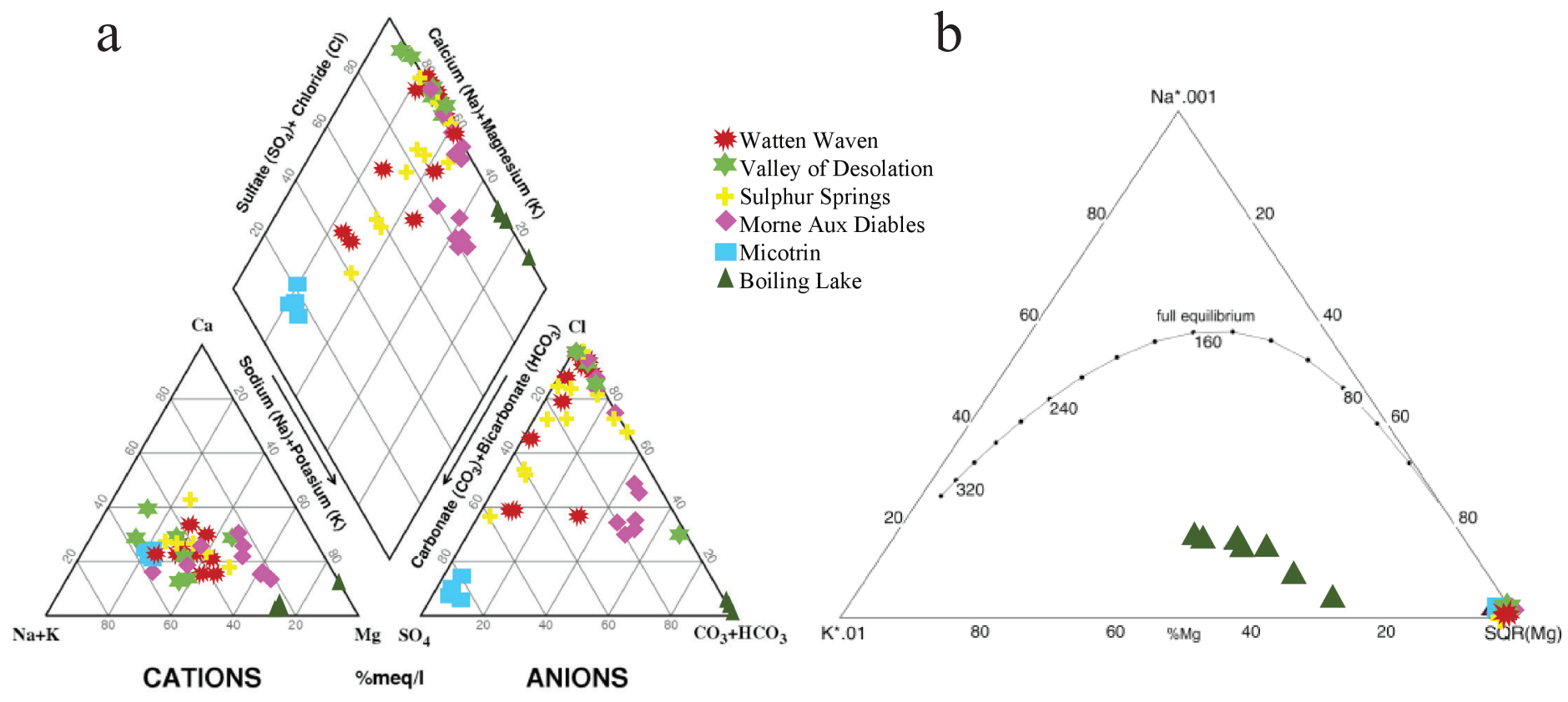

Figure 1. Chemical composition of hydrothermal waters from Dominica. (A) $\mathrm{Na}+\mathrm{K}-\mathrm{SO}_{4}-\mathrm{Mg}, \mathrm{Cl}-\mathrm{SO}_{4}-\mathrm{HCO}_{3}$ and $\mathrm{SO}_{4}+\mathrm{Cl}-\mathrm{Ca}+\mathrm{Mg}-$ $\mathrm{Na}+\mathrm{K}-\mathrm{CO}_{3}+\mathrm{HCO}_{3}$ ternary (Piper) diagrams for hydrothermal water samples from 2000-2006 and 2014-2017 giving their relative concentrations. (B) Na-K-Mg ternary diagram that displays the maturity of the waters.

chromatography and carried by helium into the isotope ratio mass spectrometry, where the delta ${ }^{18} \mathrm{O}$ ratio is then measured (Lu FH, 2009).

The use of an Isotope-Ratio Mass Spectrometer was employed for the analysis of deuterium and carbon isotopes. To acidify and flush the sample vials, the manifold system (Schauer et al, 2004) was used in order to keep everything out of the vial besides the 500 micron sample and helium for the most accurate results. The Inductively Coupled Plasma Mass Spectrometer was used to determine trace elements such as aluminum and iron.

\section{WATER GEOCHEMISTRY}

\section{General Compositions and classification}

Water chemistry comparisons, comprise of data from 2000-2006 (Joseph et al, 2011), June 2014 (Metzger, 2015), June 2015 (Defranco, 2016), June 2016 (Aragosa, 2017) and June 2017. The chemical composition of the hydrothermal waters are plotted in ternary (Piper) diagrams (Fig. 1a). Overall, the hydrothermal waters in Dominica have seen little to no major shifts in cation compositions in every area besides the Boiling Lake. However, anion composition shifts have been observed.

\section{Watten Waven}

Manifestation of hydrothermal activity at Watten Waven is in the form of streams fed by boiling waters, and bubbling fumaroles. Orange colored sediment is observed surrounding its streams and fumaroles. The water has a $\mathrm{pH}=3$ to 7 , and temperatures $=25^{\circ} \mathrm{C}$ to $89^{\circ} \mathrm{C}$. The water is primarily acid-sulfate dominated; however, some waters are sulfate-bicarbonate type in composition. These sulfate-bicarbonate waters are mostly present in the streams with higher $\mathrm{pH}$ 's and lower temperatures compared to the sulfate-based waters.

\section{Valley of Desolation}

Valley of Desolation (VoD) waters are overwhelming acid-sulfate and are characterized by $\mathrm{pH}=2$ to 7 and temperatures that range from $69^{\circ} \mathrm{C}$ to $99^{\circ} \mathrm{C}$. The springs contain dark cloudy water with bubbling fumaroles that feed into larger streams. Unlike other areas, the VoD has remained sulfate dominated since monitoring began in 2000. A consistent minor shift 
in the dominant cation from sodium toward calcium is present from 2014-2017. Less readily leachable salts in shallow ground water may play a role in this gradual shift.

\section{Boiling Lake}

The lake is contained in a $50 \mathrm{~m}$ wide, $15 \mathrm{~m}$ deep and $1.22 \times 103 \mathrm{~m}^{3}$ crater (Fournier et al, 2009), at the heart of the Morne Trois Piton volcanic complex. The waters are characterized by $\mathrm{pH}=3$ to 4 and temperatures ranging from $85^{\circ} \mathrm{C}$ to $90^{\circ} \mathrm{C}$. Unlike the other hydrothermal features, it has undergone significant changes in chemistry since 2000. The water of the Boiling Lake currently has a sodium/potassium chloride-type composition.

\section{Sulphur Springs}

Sulphur Springs waters have $\mathrm{pH}=2$ to 7 and temperatures from $35^{\circ} \mathrm{C}$ to $91^{\circ} \mathrm{C}$ dark black and darkmilky waters, vigorously bubbling fumaroles and strongly altered yellow-orange rocks/sediment. The waters have shifted towards a bicarbonate composition and now has a sulfate-bicarbonate type composition. The waters have lower sulfate concentrations on average from 2000 to 2017. The black color of the water is likely due to the precipitation of iron sulfide in the water because of the activity of high metabolic sulfate-reducing bacteria (Fauque et al, 1995).

\section{Morne Aux Diables}

Morne Aux Diables comprises an area of $1 \mathrm{~m}^{2}$ to $5 \mathrm{~m}^{2}$ with murky-white bubbling pools, heavily altered rocks/sediment coated with sulfur precipitates. The water is characterized by $\mathrm{pH}=1.4$ to 3 and low temperatures of $23^{\circ} \mathrm{C}$ to $24^{\circ} \mathrm{C}$. Similar to Watten Waven, the waters of Morne Aux Diables is primarily sulfatedominated. Unlike Watten Waven, it has seen a shift toward neutral chloride waters and a decline in sulfate content.

\section{Micotrin}

Sampling of Micotrin springs began in 2014 and is characterized as bicarbonate waters with a $\mathrm{pH}=6$ to 6.5 and temperatures $=20^{\circ} \mathrm{C}$ to $32^{\circ} \mathrm{C}$. The clear waters flow over rocks with deep orange colored surface alteration. The waters are magnesium bicarbonate in character.

\section{Table 1}

Calculated Temperatures from Fournier 1977(F), Fournier and Truesdell 1976 (F/T), Giggenbach 1988 (G), Arnorsson et al. 1983 (A), $\mathrm{Qz}^{\mathrm{a}}=$ no steam-loss, $\mathrm{Qz} \mathrm{z}^{\mathrm{b}}=$ Maximum steam-loss

\begin{tabular}{|c|c|c|c|c|c|c|c|c|c|}
\hline Sample & Site & $\begin{array}{c}\text { Surface } \\
\text { Temperature } \\
\left(C^{q}\right)\end{array}$ & $\begin{array}{c}\mathrm{Na}- \\
K \\
(F)\end{array}$ & $\begin{array}{l}\mathrm{Na-} \\
K \\
\text { (G) }\end{array}$ & $\begin{array}{l}\mathrm{Na}-\mathrm{K} \\
(\mathrm{F} / \mathrm{T})\end{array}$ & $\begin{array}{l}\mathrm{Na}- \\
\mathrm{K}-\mathrm{Ca} \\
(\mathrm{F} / \mathrm{T})\end{array}$ & $\begin{array}{c}\text { Chalcedony } \\
\text { (A) }\end{array}$ & $\begin{array}{l}Q z^{a} \\
(F)\end{array}$ & $\begin{array}{l}Q z^{b} \\
(F)\end{array}$ \\
\hline $\begin{array}{l}\text { Boiling } \\
\text { Lake }\end{array}$ & $\begin{array}{l}\text { Valley of } \\
\text { Desolation }\end{array}$ & 99 & 319 & 314 & 307 & 452 & 137 & 165 & 156 \\
\hline $\begin{array}{c}\text { Bubbling } \\
\text { Pool } 1\end{array}$ & $\begin{array}{l}\text { Valley of } \\
\text { Desolation }\end{array}$ & 79 & 308 & 305 & 293 & 347 & 103 & 131 & 128 \\
\hline $\begin{array}{l}\text { Bubbling } \\
\text { Pool } 2\end{array}$ & $\begin{array}{l}\text { Valley of } \\
\text { Desolation }\end{array}$ & 99 & 295 & 294 & 276 & 338 & 123 & 151 & 144 \\
\hline $\begin{array}{l}\text { Black } \\
\text { Water } \\
\text { Spring }\end{array}$ & $\begin{array}{l}\text { Valley of } \\
\text { Desolation }\end{array}$ & 40 & 268 & 270 & 241 & 313 & 70 & 98 & 100 \\
\hline $\begin{array}{l}\text { Nico's } \\
\text { Spring }\end{array}$ & $\begin{array}{l}\text { Sulphur } \\
\text { Springs }\end{array}$ & 91 & 150 & 163 & 100 & 223 & 159 & 185 & 172 \\
\hline $\begin{array}{l}\text { Jan's } \\
\text { Pool }\end{array}$ & $\begin{array}{l}\text { Watten } \\
\text { Waven }\end{array}$ & 59 & 341 & 332 & 337 & 351 & 61 & 90 & 92 \\
\hline $\begin{array}{c}\text { Yellow } \\
\text { Pool }\end{array}$ & $\begin{array}{l}\text { Watten } \\
\text { Waven }\end{array}$ & 78 & 339 & 331 & 335 & 351 & 74 & 102 & 103 \\
\hline $\begin{array}{l}\text { River } \\
\text { Blanc }\end{array}$ & $\begin{array}{l}\text { Watten } \\
\text { Waven }\end{array}$ & 28 & 282 & 282 & 259 & 329 & 57 & 89 & 86 \\
\hline $\begin{array}{l}\text { Eric's } \\
\text { Pool }\end{array}$ & $\begin{array}{c}\text { Morne } \\
\text { aux } \\
\text { Diables }\end{array}$ & 24 & 268 & 270 & 240 & 313 & 49 & 78 & 81 \\
\hline $\begin{array}{l}\text { Micotrin } \\
\text { Warm } \\
\text { Spring }\end{array}$ & Micotrin & 32 & 265 & 267 & 237 & 295 & 75 & 104 & 104 \\
\hline
\end{tabular}

\section{Cation/Anion 2014-2017 Comparisons}

The hydrothermal waters of Dominica have been consistently sampled since 2014. Sampling sites like Eric's Pool (Morne Aux Diables), Jan's Pool (Watten Waven) and Nico's Pool (Sulphur Springs) concentrations have stayed fairly consistent throughout the four years of sampling, only varying by $1-5 \%$ year to year for $\mathrm{Na}, \mathrm{K}, \mathrm{Mg}, \mathrm{Ca}, \mathrm{F}, \mathrm{Cl}$, and $\mathrm{HCO}_{3}$. Sulfate, on the other hand, has seen the greatest shifts in concentration from year to year. The highest concentrations of sulfate has been observed in 2015. This correlates with 2015 having the lowest precipitation $(59.8 \mathrm{~mm})$ in the four-year sampling period, based on rainfall data collection at the Canefield Airport. June 2014 saw precipitation of $104.4 \mathrm{~mm}$, while June 2016 and June 2017 saw precipitation $227.5 \mathrm{~mm}$ and $142.6 \mathrm{~mm}$ respectively. Lower precipitation leads to less dilution and higher concentrations, most significantly in sulfate. 
The Boiling Lake follows the trends in other hydrothermal areas, with the exception of its sulfate concentrations. The other hydrothermal areas have concentrations of sulfate in the hundreds and thousands of parts per million ( $\mathrm{ppm}$ ) with sulfate being the dominant anion. The Boiling Lake on the other hand, has sulfate concentrations of tens of ppm with chloride in the thousands of ppm. A high of $2189 \mathrm{ppm}$ was recorded in 2000 (Joseph et al, 2011). Since the draining events in 2004, which caused the lake to drain and refill over a period of four months (2004), there has been a yearly decline of $\mathrm{SO}_{4}$ that has never recovered since the 2004 event (Fournier et al, 2009). In November 2016, another drainage event occurred that lasted for six weeks. No change in the pattern of $\mathrm{SO}_{4}$ concentration was observed after this event.

\section{Maturity}

The Na-K-Mg ternary diagram is a powerful tool (Fahrurrozie et al, 2015) to help assess the deep equilibrium reservoir temperatures and evaluate the state of equilibrium and mixing effects of hydrothermal waters. The diagram is divided into three sections that inform on how much water-rock interaction/mixing has occurred. The top section shows the full equilibrium between the waters with the surrounding rock; the middle shows partial equilibrium between the waters and the surrounding rock and the bottom section shows if the waters are immature (Fig. 1b). Immature waters signify little to no water-rock interaction/mixing. For the purpose of geothermometry, this can help indicate which geothermometers are best suited to estimate reservoir temperatures.

The hydrothermal waters of Dominica are primarily immature. This is indicative that the waters are mixing with meteoric groundwater and are not at equilibrium with the host lithology. Due to the waters immaturity, silica based geothermometers are more useful than $\mathrm{Na}-\mathrm{K}$ geothermometers to get better estimates of reservoir temperatures. Boiling Lake shows more mixing and equilibrium than other areas.

\section{Isotope Geochemistry}

Stable isotopes can indicate the source of the water present in hydrothermal springs and groundwater reservoirs. The stable isotopes are expressed relative to the Vienna Standard Mean Ocean Water (VSMOW) in parts per thousand $(0 / 00$, per mil). The equation used for hydrogen is:

$$
\delta^{2} H-\left(\frac{2_{H} / 1_{H}(\text { sample })}{2_{H} / 1_{H}(\text { VSMOW })}-1\right) x 10^{3}
$$

and the oxygen equation used is:

$$
\delta^{18} O-\left(\frac{18_{o} / 16_{o}(\text { sample })}{18_{o} / 16_{o}(\text { VSMOW })}-1\right) \times 10^{3}
$$

Past investigations in Dominica, conducted by Joseph et al. (2011), have found that the isotopes of many of these springs lie on a trend between magmatic sources and the meteoric water line (MWL) with some influence from water-rock interaction and surface evaporation. This interpretation is based on the natural processes of the waters stable hydrogen and oxygen isotopes that are controlled by kinetic and equilibrium fractionation. The natural processes that can affect $\delta^{18} \mathrm{O}$ and $\delta^{2} \mathrm{H}$ values are shown in Figure $2 \mathrm{~b}$.

Isotope data for the hydrothermal waters of Dominica began to be regularly collected in 2015 and there is isotope data for 2002 (Joseph et al., 2011). The stable isotopes of water in the hydrothermal areas of Dominica are primarily seeing the effects evaporation from the surface year to year. 2017 on average saw a decrease in $\delta^{18} \mathrm{O}$ and $\delta^{2} \mathrm{H}$ in comparison to 2015 and 2016. Valley of Desolation's $\delta^{18} \mathrm{O}$ vs $\delta^{2} \mathrm{H}$ graph (Fig. 2 ), displays a similar trend to the Boiling Lake and Watten Waven. Sulphur Springs shows a negative shift in $\delta^{18} \mathrm{O}$ in 2017 . Though minor, this may be indicative of the increased presence of $\mathrm{CO}_{2}$, which can promote low temperature primary mineral dissolution and secondary mineral precipitation reactions. This process can preferentially consume $\delta^{18} \mathrm{O}$ (Karolyte et al., 2017; D'more and Panichi, 1987). It also means that equilibrium oxygen isotope exchange between $\mathrm{CO}_{2}$ and the water may have taken place.

\section{GEOTHERMOMETRY}

Geothermometers have the theoretical basis of a multicomponent thermodynamic calculation based on 
A

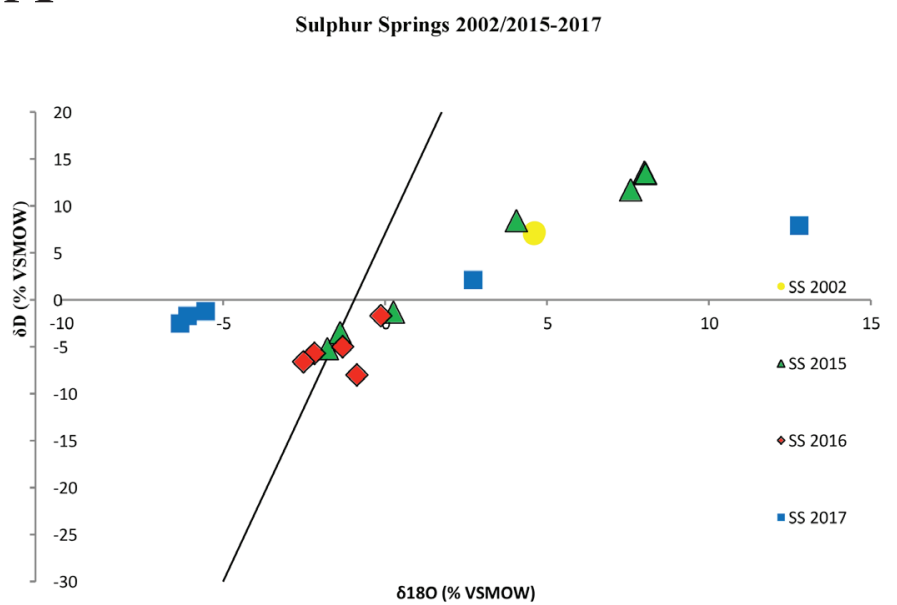

B

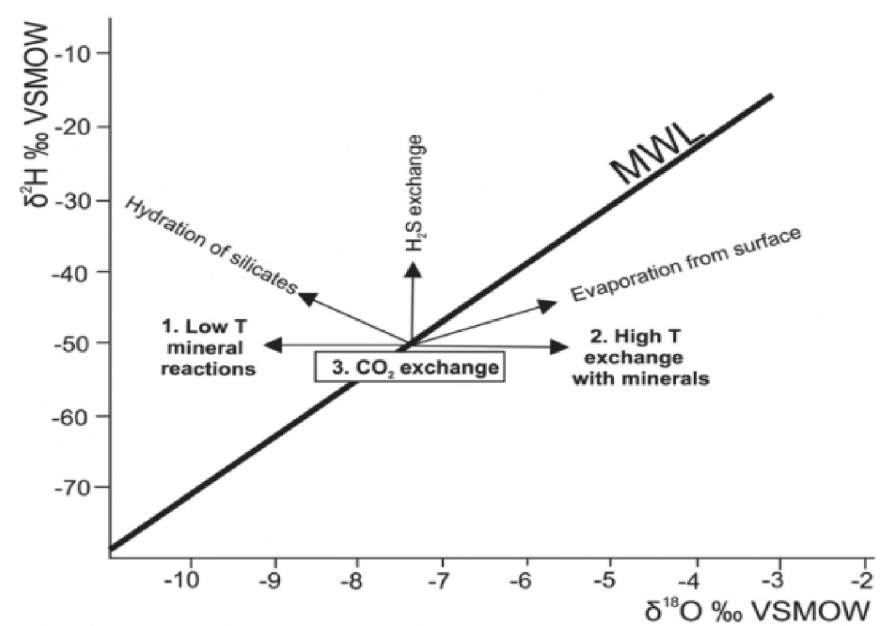

$\mathrm{C}$

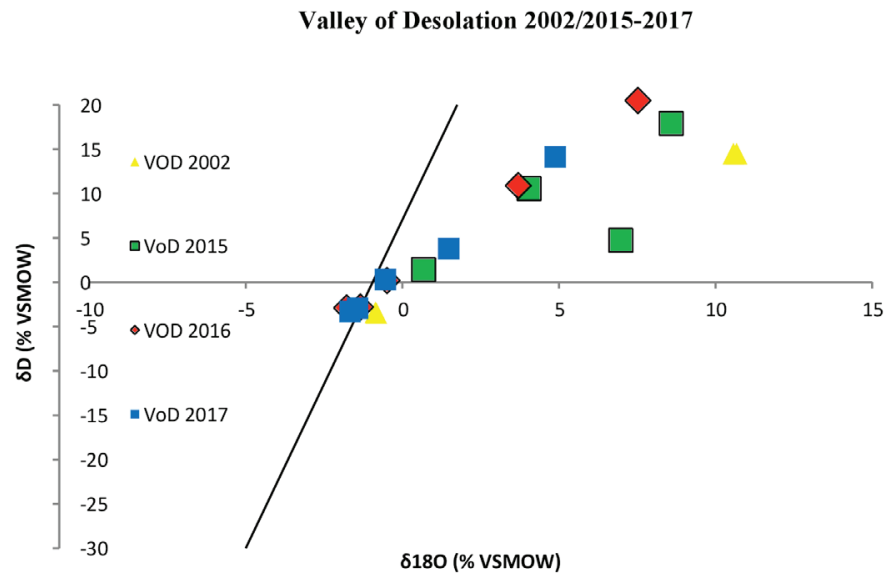

Figure 2. Stable isotope composition of hydrothermal waters from Dominica. (A) Average natural trends in $\delta^{18} \mathrm{O}$ vs $\delta^{2} H$ at Sulphur Springs. (B) Natural processes affecting water $\delta^{18} \mathrm{O}$ vs $\delta^{2} H$ values (Karolyte et al., 2017). (C) Average natural trends in $\delta^{18} \mathrm{O} v s \delta^{2} H$ at Valley of Desolation. the equilibria of water, mineral, and gas phases (Reed) et al., 1984; Wishart, 2015). It evaluates whether degassing or dilution has occurred, determines the equilibrium status of the system, and obtains temperatures if equilibrium exists for a mineral assemblage. While theoretically it is sound, in practice calculated reservoir temperatures can be less accurate due to factors like degassing and precipitation of calcium carbonate. The most accurate temperatures would come from in situ boreholes. Geothermometers still can be useful because they show increases and decreases in temperatures even if the reservoir temperature itself may not be completely accurate.

The Dominican hydrothermal waters are overwhelmingly immature (Fig. 1b). Subsequently, silica based geothermometers offer a more reliable option as compared to $\mathrm{Na} / \mathrm{K}$ geothermometers, since the host lithology has not equilibrated with the waters. Silica solubility-based geothermometers are determined by variations in the solubility of different silica species (quartz and chalcedony) in water as a function of temperature, pressure, and fluid acidity at the time of mineralization (Wishart, 2015). Silica geothermometers are best for surface temperatures above $150^{\circ} \mathrm{C}$ (below this chalcedony controls the dissolved silica content) and when the effects of steam separation are due to subsurface boiling (Yock, 2009; Karingithi, 2009). For the quartz geothermometers two equations are required, the adiabatic (maximum steam loss):

$$
T^{0} C=\frac{1522}{5.75-\log \left(\mathrm{SiO}_{2}\right)}-273.15(\text { Fournier }, 1977)
$$

and the conductive (no steam loss):

$$
T^{0} \mathrm{C}=\frac{1112}{4.91-\log \left(\mathrm{SiO}_{2}\right)}-273.15(\text { Fournier }, 1977)
$$

Na-K geothermometers work best with fluids that are from a thermal environment that are above $180^{\circ} \mathrm{C}$, contain low calcium, and have equilibrated with albite and K-spar (Yock F. 2009). Na-K-Ca geothermometers assume equilibrium between $\mathrm{Na}$ and $\mathrm{K}$-feldspar but can be affected by boiling and dilution. Thus, these both are best used for more mature and less volatile waters. However, these geothermometers still can be useful to get general temperature differences. 
Silica geothermometers were used to calculate equilibrium temperatures for the Boiling Lake, Nico's Pool and Jan's Pool for water samples in 2006 (Joseph et al., 2011). When compared with these temperatures, samples from 2017 indicate that the reservoir that feeds the Boiling Lake, has dropped by $\sim 30^{\circ} \mathrm{C}$, Sulphur Springs has seen an increase in reservoir temperature of $\sim 31^{\circ} \mathrm{C}$, while Watten Waven has no significant change in temperature.

\section{CONCLUSION}

Analysis of the hydrothermal waters of Dominica have indicated that while the origin of the hydrothermal systems are still dominantly meteoric, surface evaporation effects and variable amounts of mixing with shallow ground water plays an important role in most of the hydrothermal areas. New $\delta^{18} \mathrm{O}$ isotopic shifts in Sulphur Springs, suggest that low temperature mineral reactions are driving oxygen to exchange with $\mathrm{CO}_{2}$. This is evident by the significant $\delta^{18} \mathrm{O}$ shift from 2014 to 2016 and then again in 2017, as seen for Nico's Pool in Sulphur Springs. Variable levels of degassing year to year and the action of high metabolic sulfatereducing bacteria may possibly be the key contributing factors. Sulphur Springs has shown a significant increase in reservoir(s) temperature. Future monitoring of this site is needed to see if this trend continues. The change in chemistry of the Boiling Lake to a more chloride dominant system may be indicative of the system being fed more directly from a deeper hydrothermal brine reservoir (Fournier et al., 2009) and the calculated reservoir temperature drop may play an active role in the decline in $\mathrm{SO}_{4}$.

\section{ACKNOWLEDGEMENTS}

This material is based upon work supported by the Keck Geology Consortium and the National Science Foundation under Grant No. 1659322. The first extension of gratitude is to my research advisors Holli Frey and Erouscilla Pat Joseph. Their help, guidance and kindship were invaluable to my growing knowledge as a scientist and a person. National Science Foundation - MRI \#1229258 (Isotope ratio mass spectrometer), National Science Foundation - CCLI\#9952410 (Perkin Elmer ICP-MS), Union College - Summer Research Fellowship were all key to funding my research. Matthew Manon's assistance in the IC and ICP-MS Lab and Anouk Verheyden-Gillikin for assistance in IRMS lab. ODM in Dominica for guiding and helping us throughout our travels and Springfield Estate for the food and beds.

\section{REFERENCES}

Arnórsson, S., 2000, Isotopic and chemical techniques in geothermal exploration, development anduse. Sampling methods, data handling, interpretation. International Atomic Energy Agency,Vienna, $351 \mathrm{pp}$.

D’Amore, F., Panichi, C., 1987, Geochemistry in geothermal exploration. Appl. Geotherm. 9, $69 \mathrm{e} 89$.

Fahrurrozie, A., Saputra, M. P., \& Nugraha, T., 2013, The Application of Na-K-Mg, Na-K/Mg$\mathrm{Ca}$ and $\mathrm{K}-\mathrm{Mg} /$ Quartz Diagrams to Evaluate Water Geochemistry in West Java Geothermal Prospects, Indonesia, p. 4-7.

Fauque, G., Le Gall, J., and Barton, L. L., 1991, Sulfate-reducing and sulfur-reducing bacteria, in: Variations in Autotrophic Life (J. M. Shively and L. L. Barton, eds.) Academic Press, London, pp. 271-338.

Fournier, R.O., 1977, Chemical Geothermometers and Mixing Models for Geothermal Systems, Geothermics, p. 5, 41-50.

Fournier, N., F. Witham, M. Moreau-Fournier, and L. Bardou., 2009, Boiling Lake of Domiica, West Indies: High-temperature volcanic crater lake dynamics, J. Geophys. Res., 114.

Giggenbach, W.F., 1988, Geothermal solute equilibria. Derivation of Na-K-Mg-Ca geoindicators. Geochim Cosmochim Acta, v. 52, p. 2749-2765. Giggenbach, W. F., and Soto, R. C., 1992, Isotopic and chemical composition of water and steam discharges from volcanic-magmatic-hydrothermal systems of the 75 .

Goldsmith, S. T., Carey, A. E., Johnson, B. M, Welch, S. A., Lyons, W. B., Mcdowell,W. H., and Pigott, J. S., 2010. Stream Geochemistry, Chemical Weathering and $\mathrm{CO}_{2}$ Consumption Potential of Andesitic Terrains, Dominica, Lesser Antilles: Geochimical Cosmochimica Acta, v. 74, no. 1, p. 85-103. 
Joseph, E. P., Fournier, N. Lindsay, J. M., Robertson, R., and Beckles, D. M., 2013, Chemical and isotopic characteristics of geothermal fluids from Sulphur Springs, Saint Lucia: Volcanology and Geothermal Research, v. 254, p. 23-36.

Joseph, E. P., Fournier, N., Lindsay, J. M., Fischer, T. B., 2011, Gas and water geochemistry of geothermal systems in Dominica, Lesser Antilles island Arc:Volcanology and Geothermal Research, v. 206, p.1-14.

Karingithi, C.W., 2009, Chemical geothermometers for geothermal exploration, Short Course IV on Exploration for Geothermal Resources, v. SC-10, p. 3-7

Karolyet, R, Serno, S, Johnson, G \& Gilfillan, S., 2017, 'The influence of oxygen isotope exchange between $\mathrm{CO}_{2}$ and $\mathrm{H}_{2} \mathrm{O}$ in natural $\mathrm{CO}_{2}$-rich spring waters: implications for geothermometry' Applied Geochemistry.

Lindsay, J. M., Stasiuk, M. V., Shepherd, J. B., 2005, Geological history and potential hazards of the late Pleistocene to Recent Plat Pays volcanic complex, Dominica, Lesser Antilles: Bull Volcanol, v. 65, p. 201- 220.

Lu, F. H., 2009, Online high-precision $\delta^{2} \mathrm{H}$ and $\delta^{18} \mathrm{O}$ analysis in water by pyrolysis. Rapid Commun. Mass Spectrom., v. 23, p. 3144-3150.

Reed, M. H., Spycher, N., 1984, Calculation of pH and Mineral Equilibria in Hydrothermal Waters with Application to Geothermometry and Studies of Boiling and Dilution, Geochimica et Cosmochimica Acta, v. 48, p.1479-1492.

Schauer, A. J., Lott, M. J., Cook, C. S. and Ehleringer, J. R., 2005, An automated system for stable isotope and concentration analyses of $\mathrm{CO}_{2}$ from small atmospheric samples. Rapid Commun. Mass Spectrom., v. 19, p. 359-362.

Torres Marta E. , Mix Alan C. , Rugh William D., 2005, Precise $\delta^{13} \mathrm{C}$ analysis of dissolved inorganic carbon in natural waters using automated headspace sampling and continuous-flow mass spectrometry., Limnol. Oceanogr. Methods, v. 3.

Wishart, DeBonne., 2015, Comparison of Silica and Cation Geothermometers of Bath Hot Springs, Jamaica WI.

Yock, A., 2009, Geotermomertry in Costa Rica, Short Course on Surface Exploration for Geothermal Resources, v. SC-09, p. 2-5 